\title{
Instruments for assessing quality of life among older adults in African countries: a scoping review
}

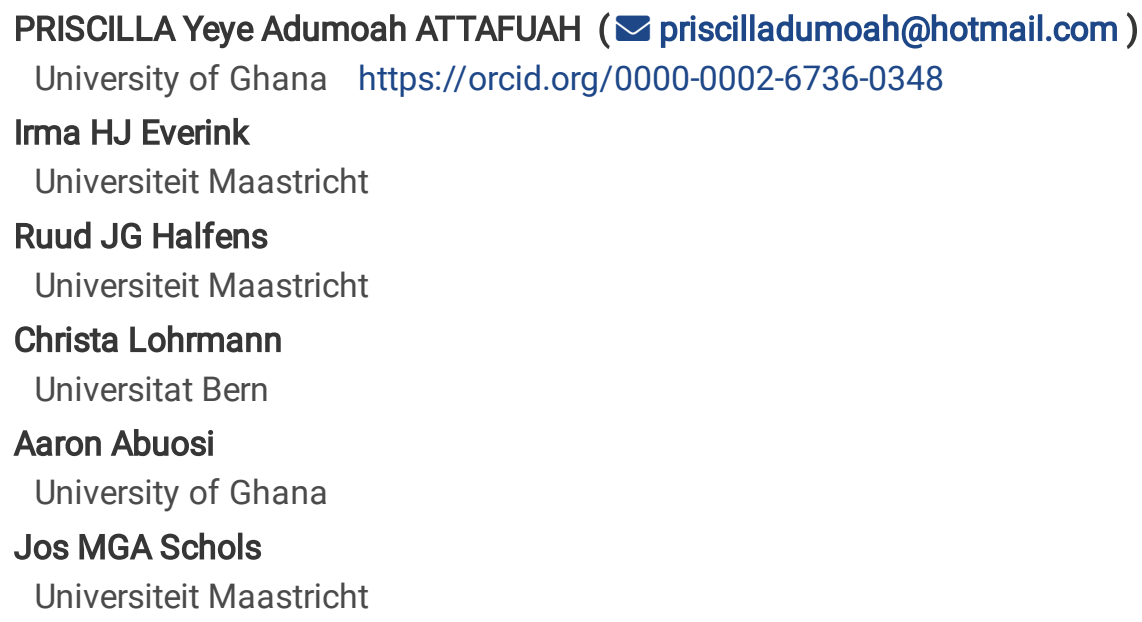

Research article

Keywords: Instruments, Quality of life, Illiterate older people, Scoping review, Slum

Posted Date: October 1st, 2019

DOI: https://doi.org/10.21203/rs.2.15430/v1

License: (1) This work is licensed under a Creative Commons Attribution 4.0 International License. Read Full License 


\section{Abstract}

Background Over $60 \%$ of the population in sub-Saharan Africa lives in informal settlements (slums) with little or no resources. To be prepared to meet the needs of older people living in slums, it is necessary to know more about their quality of life (QoL). The objective of this review is to identify instruments, which can be used by researchers to assess the QoL of older adults living in African countries, especially those dwelling in slums.

Methods A scoping review was performed using the databases Scopus, PubMed, and ISI Web of Science to retrieve studies published between January 2008 - February 2019. Studies were included if they reported generic QoL instruments, focused on adults with a mean age $\geq 50$ and were conducted in African countries.

Results In total, 22 studies were included using 14 unique instruments to measure QoL (WHOQOL, SWLS, WHOQOL-OLD, the WHOQOL-BREF, SF-36, SF-12, RAND 36, WHO-SAGE-INDEPTH, CASP-19, CASP-12, the EQ-5D+C, EQ-6D, CAF and the adapted AMS). Almost all instruments could be interviewer-administered and had the possibility for content modification to better suit the research setting. However, little is known about their psychometric properties (validity and reliability), time-investment and cultural sensitivity of the domains included in the instruments.

Conclusions Even though this review retrieved instruments used to assess QoL of older adults in African countries, there is a need for further research on adjustment and validation of currently existing QoL instruments. In addition, the development and validation of a new instrument which can be used in (illiterate) older populations, living in slums in Africa should be considered.

\section{Background}

Globally, estimates indicate that the proportion of people aged 60 years and older will increase, [1-3] by 4.3 percent between 2015 and 2030[4]. The population aged 60 years and above living in Africa is projected to be $10 \%$ of the total population by 2050 [4].

It is estimated that over $60 \%$ of the population in sub-Saharan Africa lives in informal settlements (slums) with little or no resources [5-9]. Due to scarcity of resources, living in slums also contributes to low life expectancy $[6,10,11]$. The average life expectancy rate in Africa, is as low as 48 years [12]. Nonetheless, it is only those above 50 years who are described as older adults in most African countries.

To be prepared to meet the needs of older people living in slums, it is necessary to know more about their quality of life (QoL). The WHO [13] defines Quality of Life (QoL) as 'individuals' perception of their position in life in the context of the culture and value systems in which they live and in relation to their goals, expectations, standards and concerns'. This wide concept encompasses ones physical health, psychological health, level of independence, social/family relationships, the quality of the living environment and personal beliefs. To gain more insight into the QoL of older people living in slums, we need a suitable and widely accepted instrument to measure accurately the QoL of these older people. However, there is dearth of research in the area of QoL of the ageing population in Africa [14]. Differences between African countries are large, and it might be difficult to have an instrument that would suit all African countries. However, evidence also abounds that many African countries share similar socio-economic and health challenges, including a high incidence of child and maternal mortality, HIV and malaria. Other things that African countries have in common is low government spending on health and an inadequate number and mix of health care workers, contrasted by an increasing life expectancy and proportion of older adults [56-59]. Available instruments for assessing QoL are generally developed and validated in Western countries, which have different socio-cultural and economic characteristics and different life standards compared to African countries. In addition, most older adults living in slums are illiterate, making it difficult to use QoL instruments where users have to read or write. Therefore, this study seeks to identify an instrument which can be used in African countries, to assess the QoL of older adults, especially those dwelling in slums. To retrieve this information, a scoping literature review was performed.

\section{Methods}

For this study, a scoping review was performed. The scoping review provides a descriptive overview of the analysed articles without critically appraising the quality of the included studies. We followed the first five steps in the recommendations of Levac 
et al [15] on advancing the method of scoping reviews. These recommendations are outlined as follows: 1) identifying the research question; 2) identifying relevant studies; 3) study selection; 4) data extraction; 5) analysis, reporting results, and considering the implications of study findings to policy, practice, or research.

\section{Research question}

The research question guiding this scoping review is: Which instruments are available for assessing quality of life among older adults in African countries?

\section{Identification of relevant studies}

The main literature search was conducted in May 2018 and updated in February 2019.

Several search terms were applied using the databases Scopus, PubMed, and ISI Web of Science supplemented with a free search using Google Scholar and reference harvesting. The database search query was composed of three search concepts: population (adults 50 years+), AND instrument (tools/questionnaires/measurement) AND context (developing countries), AND outcomes (quality of life) (PCO). The free words used for the population included: "frail elderly", "elder*", "senior*”, "older person*”, "old people", "aged", "aged, 50 and over", "septuagenarian*", "nonagenarian*", "octogenarian*", "centenarian*" with the Boolean operator "OR" separating them. The free words used for the context included: "developing countr*", "third-world nation*", "under developed countr*", "less developed nation*”, "developing nation*", "Africa”, "subsahar*” All words were separated by the Boolean operator "OR". The free words used for the outcome included: "Activities of Daily Living", "ADL", "quality of life", "QoL", "HealthRelated Quality Of Life". Hand searching and screening of references was done after systematic. The full search strategy is in appendix 1.

\section{Study selection}

Studies were included in the review if they met the following criteria:

- Research that used generic QoL instruments among non-disease specific populations;

- Research focused on population of adults on average 50 years and above;

- Publications written in English;

- Manuscripts published since 2008 (in order to reflect recent research developments);

- Research conducted in African countries.

In addition, the following exclusion criteria were used:

- No clear description of an instrument/questionnaire in the manuscript;

- Studies using secondary data, case studies or conference abstracts;

- Full articles that are not attainable, also after contacting authors.

Even though we are interested in finding QoL instruments which could be used in slum settings, this was not used as an inclusion criteria. It was expected that imposing this restriction would lead to limited search results.

A three-step process was followed by the authors (PYAA and IE), with the assistance of a librarian to identify relevant articles from the literature. After the literature search, all titles and abstracts of the articles were reviewed. Next, PA searched databases and did an initial elimination of articles and IE looked at the results to confirm if articles selected met the requirements. Where there were disagreements, the views of JMGAS and RJGH were sought. Finally, abstracts of articles, which met the inclusion criteria were obtained in full-text and reviewed for final eligibility. The reference lists of the included articles were also hand searched to see if any studies were missed in the initial search.

\section{Data extraction}


A data extraction sheet was developed by the authors including the following categories: authors, title, country/ population/ratio, setting (community, care homes etc.), study design, method of administration (self-administered/interviewer administered), and name of instrument used to assess QoL (Table 1). First author PA conducted the data extraction.

Next, the QoL instruments found were further assessed on reliability and validity. Both interrater and internal reliability were assessed, when available. For internal reliability a Cronbach's alpha score of $>0.70$ or an intra-class correlation close to one was considered a good score. Validity was described as if the instrument was measuring its intended purpose.

Furthermore, data was extracted on the possibility of using the instrument among an illiterate population (meaning that the instrument can be interviewer administered), the domains included in the instrument (e.g. physical functioning, pain, social functioning, etc.), on the time investment of completing the questionnaire (20 minutes or less), on the possibility of content modification of the instrument without altering the scoring sheet (meaning that the content can be modified towards items which are familiar to the research setting).

\section{Results}

Fig. 1 shows a summary of the inclusion and screening process. Databases and hand searches revealed an initial, 704 records. After duplicate records $(n=22)$ were removed, 682 records remained. Screening of titles and abstracts of these records resulted in the exclusion of 566 records that did not meet the inclusion criteria. In total, 116 articles were retrieved for detailed assessment. After screening these full-text articles, 94 articles were excluded, as they did not meet all inclusion criteria. The final number of articles included in the review was 22 (Fig. 1). Studies are grouped according to the instruments used. In total, these studies assessed QoL using seven unique instruments. The main characteristics of the 22 studies included are shown in Table 2.

\section{$<$ INSERT FIGURE 1 HERE $>$}

Titles from databases and hand search $(n=704)$

0

Titles from databases and hand search $(n=704)$

Duplicates removed $(n=22)$

00

Duplicates removed $(n=22)$

Titles and abstracts screened $(n=682)$

Titles and abstracts screened $(n=682)$

Studies excluded $(n=566)$

Title/abstract not relevant to answer research question $(n=558)$

Manuscript not attainable $(n=8)$

00

Studies excluded $(n=566)$

Title/abstract not relevant to answer research question $(n=558)$

Manuscript not attainable $(\mathrm{n}=8)$

Full text reviewed $(n=116)$

Full text reviewed $(n=116)$ 
Studies excluded $(n=94)$

Disease-specific QoL instrument $(n=24)$

Not conducted in African countries $(n=14)$

Sample population not involving older adults $>50$ years of age $(n=13)$

Disease-specific population $(n=12)$

Instrument not measuring QoL $(\mathrm{n}=8)$

QoLinstrument focused on care givers $(n=7)$

Not a primary study $(n=6)$

Instrument not described $(\mathrm{n}=3)$

Narrative literature review $(n=3)$

Full article not attainable $(n=2)$

No full text available in English language $(n=2)$

00

Studies excluded $(n=94)$

Disease-specific QoL instrument $(n=24)$

Not conducted in African countries $(n=14)$

Sample population not involving older adults $>50$ years of age $(n=13)$

Disease-specific population $(n=12)$

Instrument not measuring QoL $(\mathrm{n}=8)$

QoLinstrument focused on care givers $(n=7)$

Not a primary study $(n=6)$

Instrument not described $(\mathrm{n}=3)$

Narrative literature review $(n=3)$

Full article not attainable $(n=2)$

No full text available in English language $(n=2)$

Included 22 studies

0

Included 22 studies

Fig. 1: Schematic flow of search results

Research design 
Out of the 22 studies included 18 (81.8\%) were cross sectional studies; 2 (9\%) were cohort studies [20, 21], and 2 (9\%) studies had a longitudinal design $[22,23]$. Of the articles included, $96 \%(n=21)$ used a quantitative methodology.

\section{Participants and settings}

The number of participants included in any given study varied from 40 to 5131 subjects, totalling 29,505. The age range of participants from the studies included was between 50 and 94 years.

Most studies were conducted in South Africa ( $n=7,8957$ participants), followed by Nigeria ( $n=6 ; 2930$ participants), and Kenya ( $n=2,3950$ participants). Related to the countries Senegal, Angola, Ethiopia, Ghana, Lesotho, Tanzania and Tunisia, in each case, one study is included in this review. The community setting accounted for 18 of the included studies with the remaining four being from nursing homes or long-term care facilities. Two of the studies $[45,46]$ specifically studied slum settings. Of the 22 studies, one study specified that the instrument used was not suitable for illiterate people [24]. Another study did not report on the literacy of its participants [25]. The remaining 20 studies administered instruments to both literate and illiterate people. In these studies, the interviewer read out questions for illiterate participants and filled in their responses.

Instruments assessing QoL

In this review, 14 different instruments are found which were used to measure QoL in African countries in 22 different studies (table 1). The most often used instruments are the "World Health Organization Quality of Life Scale" (WHOQOL; $n=5)$ and the "Satisfaction with Life Scale" (SWLS; $n=4)$, followed by the "World Health Organization Quality of Life Scale-old version" (WHOQOL-OLD; $n=2$ ), the "World Health Organization Quality of Life Scale-brief version" (WHOQOL-BREF; $n=2$ ), the Short-Form Health Survey-36 (SF-36; $n=2)$, the "Short-Form Health Survey-12 (SF-12; $n=1)$, the "RAND 36" $(n=1)$, the "WHO-Study on Global Ageing and Adult Health-INDEPTH" (WHO-SAGE-INDEPTH; $\mathrm{n}=1$ ), the "Control, Autonomy, Self-Realization and Pleasure19" (CASP-19; $n=1)$, the "Control, Autonomy, Self-Realization and Pleasure-12" (CASP-12; $n=1)$, the EuroQol-5D+C" (EQ$5 D+C ; n=1)$; the EuroQol-6D (EQ-6D; $n=1)$, the "Currently Achieved Functioning" (CAF; $n=1)$, and the Aging Male Symptoms (AMS; $n=1$ ). Four of these scales were used as a combination in two studies respectively: the SWLS and the CASP-19 [47] and the EQ $-5 D+C$ and the CAF [48]. The two studies that included slum settings both used the WHOQOL to assess QoL of participants $[45,46]$.

$<$ INSERT TABLE 1 HERE>

\section{Reliability and Validity of instruments}

According to 8 studies providing figures on reliability, 5 instruments had a Cronbach's Alpha score of $\geq 0.7$ (the SWLS $(n=3)$, the SF-12 $(n=1)$ and the WHOQOL-OLD $(n=1))$, The study of Mugomeri et al. [32], using the WHOQOL-BREF reported reliability of 0.68 and the study of Hamren et al. [34] did not report on reliability of the full CASP-12 but on its subscales. Reliability of the subscales varied from 0.63 to 0.76 . One instrument (SF-36) had good intra-class correlation according to the one study reporting on it [28]. Scores on interrater reliability were not provided and 13 studies did not report on any form of reliability. Most studies (n $=18)$ stated that the instrument used had content validity. Three studies, using the SF-36 $(n=2)$ and WHOQOL $(n=1)$ did not report on any type of validity (table 2)

\section{Suitability of using instrument among illiterate population}

Almost all, $90 \%$ of the studies, used interviewer administered questionnaires. This means that these instruments are suitable to use among an illiterate population. Out of these, three studies (using four instruments: the WHOQoL-old, WHOQoL-bref, SWLS and the CASP-19) used either as a self-completed or interviewer administered instrument in different studies. This means respondents could choose between self-administration or interviewer administration of the questionnaire. In two studies, one which uses a combination of the $\mathrm{EQ}-5 \mathrm{D}+\mathrm{C}$ and $\mathrm{CAF}$ and the other study using the AMS, self-administration of the questionnaire was done.

Domains, time investment, and possibility for content modification 
As shown in table 1, the domains of the instruments used varied. All instruments assessed physical and psychological aspects of quality of life. Only the CASP-12, EQ-5D+C, CAF, EQ-6D and the adapted AMS do not have a specific social domain included. Furthermore, the environmental domain was only captured in the different versions of the WHOQOL instrument. This domain is absent in the remainder of the instruments.

With regards to time investment, completion of the instrument varied from 2-6 minutes [35] to two hours [26]. However, most studies $(n=18)$ did not provide any information on time investment.

In some cases, adapting the instrument was needed to suit the participants or research settings. Content modification appeared to be possible in 20 studies. The studies reporting on the use of the EQ-6D [28] and the combination of EQ-5D+C and CAF [47] did not provide information about this possibility. In 13 studies, instrument translation or adaptation to the local language of the population was done before the use of the instrument. In the remaining nine studies, the instruments were administered without need for translation, because either a translated form pre-existed or mode of administration was in English language. Lastly, in nine studies (using the WHOQOL, WHO-SAGE-INDEPTH, WHOQOL-OLD, SWLS, CASP-12 and EQ-6D) researchers removed or rephrase original phrases of the instruments and inserted statements that would be familiar to the population in question [14, 22, $21,30,31,32,33,34]$.

$<$ INSERT TABLE 2 HERE>

\section{Discussion}

In this review, 14 different instruments in 22 studies were found which were used to measure QoL among older adults in African countries: the WHOQO $(n=5)$, the SWLS $(n=4)$, the WHOQOL-OLD $(n=2)$, the WHOQOL-BREF $(n=2)$, the SF- $36(n=2)$, the SF$12(n=1)$, the RAND $36(n=1)$, the WHO-SAGE-INDEPTH $(n=1)$, the CASP-19 $(n=1)$, the CASP-12 $(n=1)$, the EQ-5D+C $(n=1)$, the EQ-6D $(n=1)$, the CAF $(n=1)$ and the adapted AMS $(n=1)$. After careful reflection on their respective psychometric properties, it appeared that the majority of studies reported that the instruments used were validated on content. However, studies did not describe if validation concerned validation of the original instrument or validation of the instrument for use in the countries and settings under interest. Furthermore, six studies reported good internal reliability of the instruments. These studies used the instruments SWLS $(n=3)$, SF-12 $(n=1)$ and WHOQOL-OLD $(n=1)$ and SF-36 $(n=1)$. Twelve studies did not provide any information on reliability and none of the included 22 studies reported on inter-rater reliability.

As a large proportion of older adults in African countries live in slums and are illiterate, this study also critically reviewed both the feasibility of applying the instruments in an illiterate population and the content (domains) of the instruments used. When looking at feasibility, almost all instruments are good for use among an illiterate population as there is a possibility for interviewer administration of the questionnaires. However, there is little information available on time investment of administering the instrument. Content modification of the instruments, to improve suitability of the instrument towards the population or setting, appeared to be possible in almost all instruments. These results are different from a study of Nilsson et al. [50], who assessed health-related quality of life (HRQoL) instruments to identify an instrument appropriate for older adults in rural Bangladesh. This study found $16 \mathrm{HRQ}$ oL instruments (some overlapping with the results of our review, such as the SF-36 and the WHOQOL) but they concluded that none of the instruments was suitable for use due to differences in administration methods, interpretation and scoring patterns, differences in domains and contexts and burden imposed on residents.

When looking at the domains included in the different QoL instruments found in our review, the physical, psychological and social domain appeared to be included in almost all instruments. The environmental domain, however, was only included in the different WHOQOL instruments. According to the same study of Nilsson et al. [50], it seemed as if this environmental domain is of particular importance especially relating to slum settings. In this study, additional in-depth interviews were performed to retrieve information on domains deemed important by the older adult population. This study concluded that the instruments which were found to assess HRQoL mainly looked at physical, psychological and social domains, while older adults stated that spiritual, economic and environmental domains are equally important but not present in these instruments [50]. Therefore, even though the environment is included in the different versions of the WHOQOL, this domain was absent in all other instruments found. The spiritual domain is only included in the CASP-12 and the economical domain is not included in any of the found instruments. 
From these findings, it can be concluded that the majority of the instruments found to assess QoL in African countries can be interviewer administered, providing a good starting point for use in an illiterate population. Also, the content of almost all instruments can be adapted to better suit the research population and/or setting. The SWLS $[26,27,21]$ has good reliability and content validity. However, the rest of the instruments lack basic information on reliability and/or validity. Finally, more information is needed to know if the domains used in the different instruments actually reflect quality of life of older adults living in African slums.

\section{Strengths and Limitations}

To the author's best knowledge, this is the first scoping review which identified and critically reflected on instruments for assessing QoL of older adults living in African countries. Therefore, this review provides valuable insights into instruments used to measure quality of life in African countries. Another strength of this study is the fact that framework of Levac and colleagues on advancing the method of scoping reviews were followed, resulting in an excellent methodological foundation of this scoping review [15].

This review could be subject to language bias. Studies were only included in the review if they were written in English language. As the focus of this study was quality of life in African countries, this might have led to missing publications written in another language. Furthermore, there is a chance that the search strategy did not identify all available publications on this topic. However, by consulting a librarian when creating the search strategy, we expect this bias to be minimized.

\section{Implications for future research}

As there is little information available on the psychometric properties of the instruments used to assess QoL of older adults in African countries, further research should focus on validation and reliability of the instruments used among this specific population. Furthermore, there is a need for more in-depth research on which domains are important when assessing QoL among our population of interest. Currently used instruments might not be sufficiently culturally sensitive and therefore not able to reflect the aspects older adults in African countries regard as being important when assessing quality of life. Finally, further research should also specifically focus on suitability of instruments to use in an illiterate population. Aspects such as understandability (short and clear questions) and time investment are important in this sense.

\section{Conclusions}

The aim of this scoping review was to synthesize the current body of knowledge on the instruments used to assess quality of life of older adults in African countries. The following instruments (including different versions of the instruments) were found: the WHOQOL, the SWLS, the SF, the RAND 36. The CASP and the EQ-6D.. It appeared that little information is available on the psychometric properties and the feasibility of using these instruments among older adults in African countries. Also, it is unknown in the domains used in the instruments actually reflect quality of life in this specific population. This highlights the need for further research on adjustment and validation of currently existing instruments and/or for the development and validation of a new instrument which can be used in illiterate, older populations living in African slums.

\section{Abbreviations}

ADL: Activities of Daily Living

CASP $=$ Control, Autonomy, Self-Realization and Pleasure

EQ-6D $=$ Six-Dimensional European QoL Questionnaire

QoL: Quality of Life

SF-12 = Short-Form Health Survey 12-item

SF-36 $=$ Short-Form Health Survey 
SWLS = Satisfaction with Life Scale

WHO: World Health Organization

WHOQOL-BREF = World Health Organization Quality of Life Scale- brief version

WHOQOL-OLD = World Health Organization Quality of Life Scale- old version

\section{Declarations}

Ethics approval and consent to participate

Not Applicable

Consent for publication

Not Applicable

Availability of data and materials

All data generated or analyzed during this study are included in this published article [and its supplementary information files].

Competing interests

The authors declare that they have no competing interests

\section{References}

1. Mathers CD, Stevens GA, Boerma T, White RA, Tobias MI. Causes of international increases in older age life expectancy. The Lancet. 2015 Feb 7; 385(9967):540-8.

2. Prince MJ, Wu F, Guo Y, Robledo LM, O'Donnell M, Sullivan R, Yusuf S. The burden of disease in older people and implications for health policy and practice. The Lancet. 2015 Feb 7; 385(9967):549-62.

3. Beard JR, Officer A, De Carvalho IA, Sadana R, Pot AM, Michel JP, Lloyd-Sherlock P, Epping-Jordan JE, Peeters GG, Mahanani WR, Thiyagarajan JA. The World report on ageing and health: a policy framework for healthy ageing. The Lancet. 2016 May 21;387(10033):2145-54.

4. World Health Organization. World report on ageing and health. World Health Organization; 2015 Oct 22.

5. Habitat UN. The challenge of slums: global report on human settlements 2010. London: Earthscan. 2010.

6. Bennett R, Chepngeno-Langat G, Evandrou M, Falkingham J. Resilience in the face of post-election violence in Kenya: The mediating role of social networks on wellbeing among older people in the Korogocho informal settlement, Nairobi. Social Science \& Medicine. 2015 Mar 1;128:159-67.

7. Aboderin I, Nanyonjo A. Musculoskeletal health conditions among older populations in urban slums in sub-Saharan Africa. Best Practice \& Research Clinical Rheumatology. 2017 Apr 1;31(2):115-28.

8. Aboderin I, Kano M, Owii HA. Toward "age-friendly slums"? Health challenges of older slum dwellers in Nairobi and the applicability of the age-friendly city approach. International journal of environmental research and public health. 2017 Oct 20;14(10):1259.

9. Ezeh A, Oyebode O, Satterthwaite D, Chen YF, Ndugwa R, Sartori J, Mberu B, Melendez-Torres GJ, Haregu T, Watson SI, Caiaffa W. The history, geography, and sociology of slums and the health problems of people who live in slums. The lancet. 2017 Feb 4;389(10068):547-58.

10. Robertson LJ, Szabo CP. Implementing community care in large cities and informal settlements: an African perspective. Mental Health and Illness in the City. 2017:1-24. 
11. Givens JE. Urbanization, slums, and the carbon intensity of well-being: implications for sustainable development. Human Ecology Review. 2015 Jan 1;22(1):107-28.

12. World Health Organization. World health statistics 2010. World Health Organization; 2010.

13. Wikipedia contributors. "Quality of life." Wikipedia, The Free Encyclopedia. Wikipedia, The Free Encyclopedia, 29 Jul. 2019. Web. 13 Aug. 2019

14. Ramocha LM, Louw QA, Tshabalala MD. Quality of life and physical activity among older adults living in institutions compared to the community. The South African journal of physiotherapy. 2017;73(1).

15. Levac D, Colquhoun H, O'Brien KK. Scoping studies: advancing the methodology. Implementation science. 2010 Dec;5(1):69.

16. Iglesias C, Torgerson D. Does length of questionnaire matter? A randomised trial of response rates to a mailed questionnaire. Journal of health services research \& policy. 2000 Oct;5(4):219-21.

17. Madureira MM, Ciconelli RM, Pereira RM. Quality of life measurements in patients with osteoporosis and fractures. Clinics. 2012 Nov;67(11):1315-20.

18. Talarska D, Tobis S, Kotkowiak M, Strugała M, Stanisławska J, Wieczorowska-Tobis K. Determinants of quality of life and the need for support for the elderly with good physical and mental functioning. Medical science monitor: international medical journal of experimental and clinical research. 2018;24:1604.

19. Holbrook AL, Krosnick JA, Pfent A. The causes and consequences of response rates in surveys by the news media and government contractor survey research firms. Advances in telephone survey methodology. 2008;1:499-528.,

20. Gerber AM, Botes R, Mostert A, Vorster A, Buskens E. A cohort study of elderly people in Bloemfontein, South Africa, to determine health-related quality of life and functional abilities. South African Medical Journal. 2016;106(3):298-301.;

21. Gureje O, Oladeji BD, Abiona T, Chatterji S. Profile and determinants of successful aging in the lbadan Study of Ageing. Journal of the American Geriatrics Society. 2014 May; 62(5):836-42.

22. Gómez-Olivé FX, Thorogood M, Bocquier P, Mee P, Kahn K, Berkman L, Tollman S. Social conditions and disability related to the mortality of older people in rural South Africa. International journal of epidemiology. 2014 May 15;43(5):1531-41.

23. Gomez-Olive FX, Thorogood M, Clark B, Kahn K, Tollman S. Self-reported health and health care use in an ageing population in the Agincourt sub-district of rural South Africa. Global health action. 2013 Dec 1;6(1):19305.

24. Ejechi EO. The quality of life of retired reengaged academics in Nigeria. Educational Gerontology. 2012 May 1;38(5):328-37.

25. Ogunyemi AO, Odeyemi KA, Kanma-Okafor OJ, Ladi-Akinyemi TW. Health-Related Quality of Life of the Elderly in Institutional Care and Non-Institutional Care in Southwestern Nigeria: A Comparative Study. West African journal of medicine. 2018;35(1):25-32.

26. Macia E, Duboz P, Montepare JM, Gueye L. Exploring life satisfaction among older adults in Dakar. Journal of cross-cultural gerontology. 2015 Dec 1;30(4):377-91.

27. Gutiérrez M, Tomás JM, Galiana L, Sancho P, Cebrià MA. Predicting life satisfaction of the Angolan elderly: A structural model. Aging \& Mental Health. 2013 Jan 1;17(1):94-101.

28. Akosile CO, Anukam GO, Johnson OE, Fabunmi AA, Okoye EC, Iheukwumere N, Akinwola MO. Fear of falling and quality of life of apparently-healthy elderly individuals from a Nigerian population. Journal of cross-cultural gerontology. 2014 Jun 1;29(2):201-9.

29. Akinyemi A, Aransiola J. Gender perspectives in self-assessment of quality of life of the elderly in South-Western Nigeria. Journal of comparative research in Anthropology and Sociology. 2010 Apr 1;1(1):107.

30. Van Biljon L, Nel P, Roos V. A partial validation of the WHOQOL-OLD in a sample of older people in South Africa. Global health action. $2015 \operatorname{Dec}$ 1;8(1):28209.

31. Xavier Gómez-Olivé F, Thorogood M, Clark BD, Kahn K, Tollman SM. Assessing health and well-being among older people in rural South Africa. Global Health Action. 2010 Dec 1;3(1):2126.

32. Mugomeri E, Chatanga P, Khetheng TE, Dhemba J. Quality of life of the elderly receiving old age pension in Lesotho. Journal of aging \& social policy. 2017 Aug 8;29(4):371-93.

33. Debpuur C, Welaga P, Wak G, Hodgson A. Self-reported health and functional limitations among older people in the KassenaNankana District, Ghana. Global health action. 2010 Dec 1;3(1):2151.

Page $10 / 19$ 
34. Hamren K, Chungkham HS, Hyde M. Religion, spirituality, social support and quality of life: measurement and predictors CASP-12 (v2) amongst older Ethiopians living in Addis Ababa. Aging \& mental health. 2015 Jul 3;19(7):610-21.

35. Younsi M. Health-related quality-of-life measures: evidence from Tunisian population using the SF-12 health survey. Value in health regional issues. 2015 Sep 1;7:54-66.

36. Juniper EF. Validated questionnaires should not be modified. European Respiratory Journal Nov 2009, 34 (5) 1015-1017.

37. Rolstad S, Adler J, Rydén A. Response burden and questionnaire length: is shorter better? A review and meta-analysis. Value in Health. 2011 Dec 1;14(8):1101-8.

38. Robb KA, Gatting L, Wardle J. What impact do questionnaire length and monetary incentives have on mailed health psychology survey response?. British journal of health psychology. 2017 Nov;22(4):671-85.

39. de Veras BM, da Silva Magliano CA, da Silva Santos M, da Rosa Duarte E, Raquel Blatt C, Tetelbom Stein A. Health-related quality of life in elderly: a review of the EQ-5D use. JBES: Brazilian Journal of Health Economics/Jornal Brasileiro de Economia da Saúde. 2016 Dec 1;8(3).

40. Theofilou P. Quality of Life: Definition and Measurement. Europe's journal of psychology. 2013 Feb 1; 9(1).

41. Pavot W, Diener E. Review of the satisfaction with life scale. InAssessing well-being 2009 (pp. 101-117). Springer, Dordrecht.

42. Mond JM, Rodgers B, Hay PJ, Owen C, Beumont PJ. Mode of delivery, but not questionnaire length, affected response in an epidemiological study of eating-disordered behavior. Journal of clinical epidemiology. 2004 Nov 1;57(11):1167-71.

43. Palonen M, Kaunonen M, Åstedt-Kurki P. Exploring how to increase response rates to older people. Nurse researcher. 2016 May 18; 23 (5).

44. Akosile CO, Mgbeojedo UG, Maruf FA, Okoye EC, Umeonwuka IC, Ogunniyi A. Depression, functional disability and quality of life among Nigerian older adults: prevalences and relationships. Archives of gerontology and geriatrics. 2018 Jan 1;74:39-43.

45. Wilunda B, Ng N, Williams JS. Health and ageing in Nairobi's informal settlements-evidence from the International Network for the Demographic Evaluation of Populations and Their Health (INDEPTH): a cross sectional study. BMC public health. 2015 Dec;15(1):1231.

46. Kyobutungi C, Egondi T, Ezeh A. The health and well-being of older people in Nairobi's slums. Global health action. 2010 Dec 1;3(1):2138.

47. Botes R, Vermeulen KM, Ranchor AV, Buskens E. Functional health state description and valuation by people aged 65 and over: a pilot study. BMC geriatrics. 2018 Dec;18(1):11.

48. Xavier Gómez-Olivé F, Thorogood M, Clark BD, Kahn K, Tollman SM. Assessing health and well-being among older people in rural South Africa. Global Health Action. 2010 Dec 1;3(1):2126.

49. Mwanyangala M, Mayombana C, Urassa H, Charles J, Mahutanga C, Abdullah S, Nathan R. Health status and quality of life among older adults in rural Tanzania. Global health action. 2010 Dec 1;3(1):2142.

50. Nilsson J, Parker MG, Kabir ZN. Assessing health-related quality of life among older people in rural Bangladesh. Journal of Transcultural Nursing. 2004 Oct;15(4):298-307.

\section{Tables}

Table 1. Characteristics of included studies 


\begin{tabular}{|c|c|c|c|c|c|c|}
\hline Authors, year & Title & $\begin{array}{l}\text { Country / } \\
\text { Language }\end{array}$ & $\begin{array}{l}\text { Study } \\
\text { design }\end{array}$ & $\begin{array}{l}\text { Population, } \\
\text { minimum age } \\
\text { literacy level }\end{array}$ & Setting & $\begin{array}{l}\text { QoL } \\
\text { instrument } \\
\text { used }\end{array}$ \\
\hline $\begin{array}{l}\text { Xavier Gómez- } \\
\text { Olivé et al, } \\
2010 \text { [31] }\end{array}$ & $\begin{array}{l}\text { Assessing health and well-being among } \\
\text { older people in rural South Africa. }\end{array}$ & $\begin{array}{l}\text { South } \\
\text { Africa }\end{array}$ & $\begin{array}{l}\text { Cross } \\
\text { sectional } \\
\text { study }\end{array}$ & $\begin{array}{ll}\text { - } & \mathrm{n}=4085 \\
\text { - } & \text { Age }=>50 \\
& \text { years } \\
\text { - } & \text { Literates } \\
\text { and } \\
\text { illiterates }\end{array}$ & Community & WHOQOL \\
\hline $\begin{array}{l}\text { Wilunda, et } \\
\text { al, } 2015[45]\end{array}$ & $\begin{array}{l}\text { Health and ageing in Nairobi's informal } \\
\text { settlements- evidence from the INDEPTH: a } \\
\text { cross sectional study }\end{array}$ & Kenya & $\begin{array}{l}\text { Cross } \\
\text { sectional }\end{array}$ & $\begin{array}{l}\text { - } \mathrm{n}=1878 \\
\text { - Age > } 50 \\
\text { years } \\
\text { - Literates } \\
\text { and } \\
\text { illiterates }\end{array}$ & $\begin{array}{l}\text { Community } \\
\text { /Slum }\end{array}$ & WHOQOL \\
\hline $\begin{array}{l}\text { Kyobutungi, et } \\
\text { al, } 2010[46]\end{array}$ & $\begin{array}{l}\text { The health and well-being of older people in } \\
\text { Nairobi's slums }\end{array}$ & Kenya & $\begin{array}{l}\text { Cross } \\
\text { sectional } \\
\text { study }\end{array}$ & $\begin{array}{l}\text { - } \mathrm{n}=2072 \\
\text { - Age > } 50 \\
\text { years } \\
\text { - Literates } \\
\text { and } \\
\text { illiterates }\end{array}$ & Slum & WHOQOL \\
\hline $\begin{array}{l}\text { Gómez-Olivé } \\
\text { et al, } 2014 \\
\text { [22] }\end{array}$ & $\begin{array}{l}\text { Social conditions and disability related to } \\
\text { the mortality of older people in rural South } \\
\text { Africa. }\end{array}$ & $\begin{array}{l}\text { South } \\
\text { Africa }\end{array}$ & $\begin{array}{l}\text { Longitudinal } \\
\text { study }\end{array}$ & $\begin{array}{l}\text { - } \mathrm{n}=4047 \\
\text { - } 75.2 \% \\
\text { female } \\
\text { - Age > } 50 \\
\text { years } \\
\text { - Literates } \\
\text { and } \\
\text { illiterates }\end{array}$ & Community & WHOQOL \\
\hline $\begin{array}{l}\text { Gómez-Olivé } \\
\text { et al, } 2013 \\
\text { [23] }\end{array}$ & $\begin{array}{l}\text { Self-reported health and health care use in } \\
\text { an ageing population in the Agincourt sub- } \\
\text { district of rural South Africa. }\end{array}$ & $\begin{array}{l}\text { South } \\
\text { Africa }\end{array}$ & $\begin{array}{l}\text { Longitudinal } \\
\text { study }\end{array}$ & $\begin{array}{ll}\text { - } \mathrm{n}=425 \\
\text { - } 66.8 \% \\
\text { female } \\
\text { - Age > } 50 \\
\text { years } \\
\text { - Literates } \\
\text { and } \\
\text { illiterates }\end{array}$ & Community & WHOQOL \\
\hline $\begin{array}{l}\text { Macia et al, } \\
2015[26]\end{array}$ & $\begin{array}{l}\text { Exploring Life Satisfaction Among Older } \\
\text { Adults in Dakar. }\end{array}$ & Senegal & $\begin{array}{l}\text { Cross } \\
\text { sectional } \\
\text { study }\end{array}$ & $\begin{array}{l}\text { - } \mathrm{n}=500 \\
\text { - Age > } 50 \\
\text { years } \\
\text { - Literates } \\
\text { and } \\
\text { illiterates }\end{array}$ & Community & SWLS \\
\hline $\begin{array}{l}\text { Gureje et al, } \\
2014[21]\end{array}$ & $\begin{array}{l}\text { Profile and determinants of successful aging } \\
\text { in the Ibadan Study of Ageing. }\end{array}$ & Nigeria & $\begin{array}{l}\text { Cohort } \\
\text { study }\end{array}$ & $\begin{array}{l}\text { - } \mathrm{n}=930 \\
\text { - } 38.9 \% \\
\text { Female_ } \\
\text { - } \text { Age > } 65 \\
\text { years }\end{array}$ & Community & SWLS \\
\hline
\end{tabular}




\begin{tabular}{|c|c|c|c|c|c|c|}
\hline & & & & $\begin{array}{l}\text { - Literates } \\
\text { and } \\
\text { illiterates }\end{array}$ & & \\
\hline $\begin{array}{l}\text { Gutiérrez et } \\
\text { al, } 2013 \text { [27] }\end{array}$ & $\begin{array}{l}\text { Predicting life satisfaction of the Angolan } \\
\text { elderly: a structural model. }\end{array}$ & Angola & $\begin{array}{l}\text { Cross } \\
\text { sectional } \\
\text { study }\end{array}$ & $\begin{array}{ll}\text { - } & \mathrm{n}=1003 \\
\text { - } & 65.4 \% \\
& \text { females } \\
\text { - } & \text { Age > } 60 \\
& \text { years } \\
\text { - } & \text { Literates } \\
& \text { and } \\
\text { illiterates }\end{array}$ & $\begin{array}{l}\text { Long-term } \\
\text { care } \\
\text { facilities }\end{array}$ & SWLS \\
\hline $\begin{array}{l}\text { Ejechi, } 2012 \\
{[24]}\end{array}$ & $\begin{array}{l}\text { The Quality of Life of Retired Reengaged } \\
\text { Academics in Nigeria }\end{array}$ & $\begin{array}{l}\text { Nigeria/ } \\
\text { English }\end{array}$ & $\begin{array}{l}\text { Cross } \\
\text { sectional } \\
\text { study }\end{array}$ & $\begin{array}{l}\text { - } \mathrm{n}=226 \\
\text { - } 33.6 \% \\
\text { female } \\
\text { - Age > } 65 \\
\text { years } \\
\text { - Only } \\
\text { literates }\end{array}$ & Community & $\begin{array}{l}\text { SWLS and } \\
\text { CASP-19 }\end{array}$ \\
\hline $\begin{array}{l}\text { Van Biljon et } \\
\text { al, } 2015[30]\end{array}$ & $\begin{array}{l}\text { A partial validation of the WHOQOL-OLD in } \\
\text { a sample of older people in South Africa }\end{array}$ & $\begin{array}{l}\text { South } \\
\text { Africa/ } \\
\text { Afrikaans }\end{array}$ & $\begin{array}{l}\text { Cross } \\
\text { sectional } \\
\text { study }\end{array}$ & 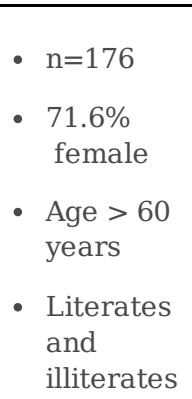 & $\begin{array}{l}\text { Long Term } \\
\text { Facilities }\end{array}$ & $\begin{array}{l}\text { WHOQOL- } \\
\text { OLD }\end{array}$ \\
\hline $\begin{array}{l}\text { Akosile et al, } \\
2018 \text { [44] }\end{array}$ & $\begin{array}{l}\text { Depression, functional disability and quality } \\
\text { of life among Nigerian older adults: } \\
\text { Prevalences and relationships. }\end{array}$ & Nigeria & $\begin{array}{l}\text { Cross } \\
\text { sectional } \\
\text { study }\end{array}$ & $\begin{array}{l}\text { - } \mathrm{n}=206 \\
\text { - } 56.3 \% \\
\text { female } \\
\text { - Age > } 65 \\
\text { years } \\
\text { - Literates } \\
\text { and } \\
\text { illiterates }\end{array}$ & Community & $\begin{array}{l}\text { WHOQOL- } \\
\text { OLD }\end{array}$ \\
\hline $\begin{array}{l}\text { Mugomeri et } \\
\text { al, } 2017 \text { [32] }\end{array}$ & $\begin{array}{l}\text { Quality of Life of the Elderly Receiving Old } \\
\text { Age Pension in Lesotho. }\end{array}$ & Lesotho & $\begin{array}{l}\text { Cross } \\
\text { sectional } \\
\text { study }\end{array}$ & $\begin{array}{l}\text { - } \mathrm{n}=385 \\
\text { - Age > } 70 \\
\text { years } \\
\text { - Literates } \\
\text { and } \\
\text { illiterates }\end{array}$ & Community & $\begin{array}{l}\text { WHOQOL- } \\
\text { BREF }\end{array}$ \\
\hline $\begin{array}{l}\text { Mwanyangala, } \\
\text { et al, } 2010 \\
{[49]}\end{array}$ & $\begin{array}{l}\text { Health status and quality of life among older } \\
\text { adults in rural Tanzania }\end{array}$ & Tanzania & $\begin{array}{l}\text { Cross- } \\
\text { sectional } \\
\text { study }\end{array}$ & $\begin{array}{l} \\
\text { - } \mathrm{n}=5131 \\
\text { - Age }>50 \\
\text { years } \\
\text { - Literates } \\
\text { and } \\
\text { illiterates }\end{array}$ & Community & $\begin{array}{l}\text { WHOQOL- } \\
\text { BREF }\end{array}$ \\
\hline $\begin{array}{l}\text { Younsi, } 2015 \\
\text { [35] }\end{array}$ & $\begin{array}{l}\text { Health-Related Quality-of-Life Measures: } \\
\text { Evidence from Tunisian Population Using } \\
\text { the SF-12 Health Survey }\end{array}$ & Tunisia & $\begin{array}{l}\text { Cross } \\
\text { sectional } \\
\text { study }\end{array}$ & - $\mathrm{n}=3864$ & Community & SF-12 \\
\hline
\end{tabular}




\begin{tabular}{|c|c|c|c|c|c|c|}
\hline & & & & $\begin{array}{l}\text { - } 51.9 \% \\
\text { Female } \\
\text { - Age 18-85 } \\
\text { years (50- } \\
\text { 59: } \mathrm{n}=711 \text {; } \\
\text { 60-74: } \\
\mathrm{n}=580 ; 75- \\
\text { 85: } 224) \\
\text { - Literates } \\
\text { and } \\
\text { illiterates }\end{array}$ & & \\
\hline $\begin{array}{l}\text { Akosile et al, } \\
2014 \text { [28] }\end{array}$ & $\begin{array}{l}\text { Fear of Falling and Quality of Life of } \\
\text { Apparently-Healthy Elderly Individuals from } \\
\text { a Nigerian Population }\end{array}$ & $\begin{array}{l}\text { Nigeria/ } \\
\text { English }\end{array}$ & $\begin{array}{l}\text { Cross } \\
\text { sectional } \\
\text { study }\end{array}$ & $\begin{array}{l}\text { - } \mathrm{n}=261 \\
\text { - } 49.8 \% \\
\text { female } \\
\text { - Age > } 65 \\
\text { years } \\
\text { - Literates } \\
\text { and } \\
\text { illiterates }\end{array}$ & Community & SF-36 \\
\hline $\begin{array}{l}\text { Ogunyemi et } \\
\text { al, } 2018 \text { [25] }\end{array}$ & $\begin{array}{l}\text { Health-Related Quality of Life of the Elderly } \\
\text { in Institutional Care and Non-Institutional } \\
\text { Care in Southwestern Nigeria: A } \\
\text { Comparative Study. }\end{array}$ & Nigeria & $\begin{array}{l}\text { Cross } \\
\text { sectional } \\
\text { study }\end{array}$ & $\begin{array}{l}\text { - } \mathrm{n}=360 \\
\text { - } \text { Age }>60 \\
\text { years }\end{array}$ & Community & SF-36 \\
\hline $\begin{array}{l}\text { Ramocha et } \\
\text { al, } 2017 \text { [14] }\end{array}$ & $\begin{array}{l}\text { Quality of life and physical activity among } \\
\text { older adults living in institutions compared } \\
\text { to the community }\end{array}$ & $\begin{array}{l}\text { South } \\
\text { Africa }\end{array}$ & $\begin{array}{l}\text { Cross } \\
\text { sectional } \\
\text { study }\end{array}$ & $\begin{array}{l}\text { - } \mathrm{n}=80 \\
\text { - Age > } 60 \\
\text { years } \\
\text { - Literates } \\
\text { and } \\
\text { illiterates }\end{array}$ & $\begin{array}{l}\text { Community } \\
\text { and care } \\
\text { homes }\end{array}$ & RAND 36 \\
\hline $\begin{array}{l}\text { Debpuur, et } \\
\text { al, } 2010 \text { [33] }\end{array}$ & $\begin{array}{l}\text { Self-reported health and functional } \\
\text { limitations among older people in the } \\
\text { Kassena-Nankana District, Ghana }\end{array}$ & Ghana & $\begin{array}{l}\text { Cross- } \\
\text { sectional } \\
\text { survey }\end{array}$ & $\begin{array}{l}\text { - } \mathrm{n}=4584 \\
\text { - Age > } 50 \\
\text { years } \\
\text { - Literates } \\
\text { and } \\
\text { illiterates }\end{array}$ & Community & $\begin{array}{l}\text { WHO- } \\
\text { SAGE- } \\
\text { INDEPTH }\end{array}$ \\
\hline $\begin{array}{l}\text { Hamren et al, } \\
2014 \text { [34] }\end{array}$ & $\begin{array}{l}\text { Religion, spirituality, social support and } \\
\text { quality of life: measurement and predictors } \\
\text { CASP-12 (v2) amongst older Ethiopians } \\
\text { living in Addis Ababa }\end{array}$ & $\begin{array}{l}\text { Ethiopia/ } \\
\text { Amharic }\end{array}$ & $\begin{array}{l}\text { Cross } \\
\text { sectional } \\
\text { study }\end{array}$ & $\begin{array}{ll}\text { - } & \mathrm{n}=214 \\
\text { - } & 51.4 \% \\
& \text { female } \\
\text { - } & \text { Age > } 55 \\
& \text { years } \\
\text { - } & \text { Literates } \\
\text { and } \\
\text { illiterates }\end{array}$ & Community & CASP-12 \\
\hline $\begin{array}{l}\text { Botes et al, } \\
2018[47]\end{array}$ & $\begin{array}{l}\text { Functional health state description and } \\
\text { valuation by people aged } 65 \text { and over: a pilot } \\
\text { study. }\end{array}$ & $\begin{array}{l}\text { South } \\
\text { Africa }\end{array}$ & $\begin{array}{l}\text { Cross } \\
\text { sectional } \\
\text { study }\end{array}$ & $\begin{array}{l}\text { - } \mathrm{n}=40 \\
\text { - } \text { Age: }>65 \\
\mathrm{n}=40 \\
\text { - Literates } \\
\text { and } \\
\text { illiterates }\end{array}$ & Community & $\begin{array}{l}\mathrm{EQ}-5 \mathrm{D}+\mathrm{C} \\
\text { and } \mathrm{CAF}\end{array}$ \\
\hline $\begin{array}{l}\text { Gerber et al, } \\
2016[20]\end{array}$ & $\begin{array}{l}\text { A cohort study of elderly people in } \\
\text { Bloemfontein, South Africa, to determine }\end{array}$ & $\begin{array}{l}\text { South } \\
\text { Africa/ }\end{array}$ & $\begin{array}{l}\text { Cohort } \\
\text { study }\end{array}$ & - $\mathrm{n}=104$ & $\begin{array}{l}\text { Nursing } \\
\text { Homes }\end{array}$ & EQ-6D \\
\hline
\end{tabular}




\begin{tabular}{|c|c|c|c|c|c|c|}
\hline & $\begin{array}{l}\text { health-related quality of life and functional } \\
\text { abilities }\end{array}$ & English & & $\begin{array}{ll}\text { - } & 72.1 \% \\
& \text { Female } \\
\text { - } & \text { Age: } \geq 65 \\
& \text { years } \\
\text { - } & \text { Literates } \\
\text { and } \\
\text { illiterates }\end{array}$ & & \\
\hline $\begin{array}{l}\text { Akinyemi et } \\
\text { al, } 2010 \text { [29] }\end{array}$ & $\begin{array}{l}\text { Gender perspectives in self-assessment of } \\
\text { quality of life of the elderly in South- } \\
\text { Western Nigeria }\end{array}$ & Nigeria & $\begin{array}{l}\text { Cross } \\
\text { sectional } \\
\text { study }\end{array}$ & $\begin{array}{l}\text { - } \mathrm{n}=947 \\
\text { - Age: }>60 \\
\text { years } \\
\text { - Literates } \\
\text { and } \\
\text { illiterates }\end{array}$ & Community & $\begin{array}{l}\text { Adapted } \\
\text { AMS }\end{array}$ \\
\hline
\end{tabular}

WHOQOL = World Health Organization Quality of Life Scale; SWLS = Satisfaction with Life Scale; WHOQOL-OLD = World Health Organization Quality of Life Scale- OLD version; WHOQOL-BREF = World Health Organization Quality of Life Scale- brief version; SF-36 =Short-Form Health Survey-36 item; SF-12 = Short-Form Health Survey 12-item; WHO-SAGE-INDEPTH = World Health Organization Study on Global Ageing and Adult Health-INDEPTH; CASP = Control, Autonomy, Self-Realization and Pleasure; EQ-5D+C = EuroQol-5D+C; $\mathrm{CAF}=$ Currently Achieved Functioning; EQ-6D = Six-Dimensional EuroQoL; AMS = Aging Male Symptoms.

Table 2. Characteristics of QoL instruments 


\begin{tabular}{|c|c|c|c|c|c|c|c|c|c|}
\hline Authors, year & $\begin{array}{l}\text { QoL } \\
\text { instrument } \\
\text { used }\end{array}$ & Reliability & Validity & $\begin{array}{l}\text { Suitable } \\
\text { for } \\
\text { illiterates }\end{array}$ & $\begin{array}{l}\text { Domains of } \\
\text { instrument }\end{array}$ & Time & $\begin{array}{l}\text { Admini- } \\
\text { stration }\end{array}$ & Language & $\begin{array}{l}\text { Content } \\
\text { modification } \\
\text { possible } \\
\end{array}$ \\
\hline $\begin{array}{l}\text { Xavier } \\
\text { Gómez-Olivé } \\
\text { et al, } 2010 \\
\text { [31] }\end{array}$ & WHOQOL & ND & ND & Yes & $\begin{array}{l}\text { (1) physical, (2) } \\
\text { psychological, (3) } \\
\text { social, (4) } \\
\text { environmental }\end{array}$ & ND & IA & Shangaan & Yes \\
\hline $\begin{array}{l}\text { Wilunda et al, } \\
2015 \text { [45] }\end{array}$ & WHOQOL & ND & Valid & Yes & $\begin{array}{l}\text { (1) physical, (2) } \\
\text { psychological, (3) } \\
\text { social, (4) } \\
\text { environmental }\end{array}$ & ND & IA & English & Yes \\
\hline $\begin{array}{l}\text { Kyobutungi et } \\
\text { al, } 2010 \text { [46] }\end{array}$ & WHOQOL & ND & Valid & Yes & $\begin{array}{l}\text { (1) physical, (2) } \\
\text { psychological, (3) } \\
\text { social, (4) } \\
\text { environmental }\end{array}$ & ND & IA & English & Yes \\
\hline $\begin{array}{l}\text { Gómez-Olivé } \\
\text { et al, } 2014 \\
\text { [22] }\end{array}$ & WHOQOL & ND & Valid & Yes & $\begin{array}{l}\text { Subscales (1) } \\
\text { satisfaction with } \\
\text { own health, (2) } \\
\text { personal and } \\
\text { social relations, } \\
\text { (3) performing } \\
\text { daily activities, (4) } \\
\text { satisfaction with } \\
\text { life }\end{array}$ & ND & IA & Shangaan & Yes \\
\hline $\begin{array}{l}\text { Gómez-Olivé } \\
\text { et al, } 2013 \\
\text { [23] }\end{array}$ & WHOQOL & ND & Valid & Yes & $\begin{array}{l}\text { Subscales (1) } \\
\text { general health, (2) } \\
\text { satisfaction with } \\
\text { life }\end{array}$ & ND & IA & Xitsonga & Yes \\
\hline $\begin{array}{l}\text { Macia et al, } \\
2015 \text { [26] }\end{array}$ & SWLS & $\begin{array}{l}\text { Cronbachs } \\
\alpha=0.82\end{array}$ & valid & Yes & $\begin{array}{l}\text { (1) mobility, (2) } \\
\text { self-care, (3) pain } \\
\text { and discomfort, } \\
\text { (4) cognition, (5) } \\
\text { interpersonal } \\
\text { activities, (6), } \\
\text { vision, (7) } \\
\text { sleep/energy, (8) } \\
\text { affect }\end{array}$ & $\begin{array}{l}1-2 \\
\text { hours }\end{array}$ & IA & English & Yes \\
\hline $\begin{array}{l}\text { Gureje et al, } \\
2014 \text { [21] }\end{array}$ & SWLS & $\begin{array}{l}\text { Cronbachs } \alpha \\
=0.81\end{array}$ & Valid & Yes & $\begin{array}{l}\text { (1) mobility, (2) } \\
\text { self-care, (3) pain } \\
\text { and discomfort, } \\
\text { (4) cognition, (5) } \\
\text { interpersonal } \\
\text { activities, (6), } \\
\text { vision, (7) } \\
\text { sleep/energy, (8) } \\
\text { affect }\end{array}$ & ND & IA & Yoruba & Yes \\
\hline $\begin{array}{l}\text { Gutiérrez et } \\
\text { al, } 2013 \text { [27] }\end{array}$ & SWLS & $\begin{array}{l}\text { Cronbachs } \alpha= \\
0.92\end{array}$ & Valid & Yes & $\begin{array}{l}\text { (1) life } \\
\text { satisfaction, (2) } \\
\text { perceived health, } \\
\text { (3) social support, } \\
\text { (4) emotional } \\
\text { support, (5) social } \\
\text { acceptance, } \\
\text { (6)physical } \\
\text { activity, (7) } \\
\text { dependency, (8) } \\
\text { generativity }\end{array}$ & $\begin{array}{l}30 \\
\text { mins }\end{array}$ & $\mathrm{SA} / \mathrm{IA}$ & Portuguese & Yes \\
\hline $\begin{array}{l}\text { Ejechi, } 2012 \\
\text { [24] }\end{array}$ & $\begin{array}{l}\text { SWLS and } \\
\text { CASP-19 }\end{array}$ & ND & Valid & Unknown & $\begin{array}{l}\text { (1) physical } \\
\text { health, (2) life } \\
\text { satisfaction, (3) } \\
\text { happiness, (4) } \\
\text { psychological well- } \\
\text { being, (5) control, } \\
\text { (6) autonomy, (7), } \\
\text { self-realization, } \\
\text { (8) pleasure }\end{array}$ & ND & SA & English & Yes \\
\hline $\begin{array}{l}\text { Van Biljon et } \\
\text { al, } 2015 \text { [30] }\end{array}$ & $\begin{array}{l}\text { WHOQOL- } \\
\text { OLD }\end{array}$ & $\begin{array}{l}\text { Cronbachs } \\
\alpha=0.80\end{array}$ & Valid & Yes & $\begin{array}{l}\text { (1) sensory } \\
\text { abilities, (2) } \\
\text { autonomy, (3) }\end{array}$ & ND & SA / IA & Afrikaans & Yes \\
\hline
\end{tabular}




\begin{tabular}{|c|c|c|c|c|c|c|c|c|c|}
\hline & & & & & $\begin{array}{l}\text { past, present, and } \\
\text { future activities, } \\
\text { (4) social } \\
\text { participation, (5) } \\
\text { death and dying, } \\
\text { (6) intimacy }\end{array}$ & & & & \\
\hline $\begin{array}{l}\text { Akosile et al, } \\
2018 \text { [44] }\end{array}$ & $\begin{array}{l}\text { WHOQoL- } \\
\text { OLD }\end{array}$ & ND & Valid & Yes & $\begin{array}{l}\text { (1) sensory } \\
\text { abilities, (2) } \\
\text { autonomy, (3) } \\
\text { past, present, and } \\
\text { future activities, } \\
\text { (4) social } \\
\text { participation, (5) } \\
\text { death and dying, } \\
\text { (6) intimacy } \\
\end{array}$ & ND & IA & English & Yes \\
\hline $\begin{array}{l}\text { Mugomeri et } \\
\text { al, } 2017 \text { [32] }\end{array}$ & $\begin{array}{l}\text { WHOQOL- } \\
\text { BREF }\end{array}$ & $\begin{array}{l}\text { Cronbachs } \alpha> \\
0.68\end{array}$ & Valid & Yes & $\begin{array}{l}\text { (1) physical, (2) } \\
\text { psychological, (3) } \\
\text { social, (4) } \\
\text { environmental }\end{array}$ & ND & IA & Sesotho & Yes \\
\hline $\begin{array}{l}\text { Mwanyangala } \\
\text { et al, } 2010 \\
{[49]}\end{array}$ & $\begin{array}{l}\text { WHOQOL- } \\
\text { Bref }\end{array}$ & ND & Valid & Yes & $\begin{array}{l}\text { (1) physical, (2) } \\
\text { psychological, (3) } \\
\text { social, (4) } \\
\text { environmental }\end{array}$ & ND & IA & Kiswahili & Yes \\
\hline $\begin{array}{l}\text { Younsi, } 2015 \\
{[35]}\end{array}$ & SF-12 & $\begin{array}{l}\text { Cronbachs } \alpha= \\
0.76\end{array}$ & Valid & Yes & $\begin{array}{l}\text { (1) physical } \\
\text { functioning, (2) } \\
\text { physical role } \\
\text { limitation, (3) } \\
\text { bodily pain, (4) } \\
\text { general health, (5) } \\
\text { vitality, (6) social } \\
\text { functioning, (7) } \\
\text { role limitation doe } \\
\text { to emotional } \\
\text { problems, (8) } \\
\text { mental health }\end{array}$ & $\begin{array}{l}2-6 \\
\text { mins }\end{array}$ & IA & Tunisian & Yes \\
\hline $\begin{array}{l}\text { Akosile et al, } \\
2014 \text { [28] }\end{array}$ & SF-36 & ICC $=0.93$ & ND & Yes & $\begin{array}{l}\text { (1) physical } \\
\text { functioning, (2) } \\
\text { physical role } \\
\text { limitation, (3) } \\
\text { bodily pain, (4) } \\
\text { general health, (5) } \\
\text { vitality, (6) social } \\
\text { functioning, (7) } \\
\text { role limitation doe } \\
\text { to emotional } \\
\text { problems, (8) } \\
\text { mental health }\end{array}$ & ND & IA & English & Yes \\
\hline $\begin{array}{l}\text { Ogunyemi et } \\
\text { al, } 2018 \text { [25] }\end{array}$ & SF-36 & ND & ND & Yes & $\begin{array}{l}\text { (1) physical } \\
\text { functioning, (2) } \\
\text { physical role } \\
\text { limitation, (3) } \\
\text { bodily pain, (4) } \\
\text { general health, (5) } \\
\text { vitality, (6) social } \\
\text { functioning, (7) } \\
\text { role limitation doe } \\
\text { to emotional } \\
\text { problems, (8) } \\
\text { mental health } \\
\end{array}$ & ND & IA & English & Yes \\
\hline $\begin{array}{l}\text { Ramocha et } \\
\text { al, } 2017 \text { [14] }\end{array}$ & RAND 36 & ND & Valid & Yes & $\begin{array}{l}\text { (1) physical } \\
\text { functioning, (2) } \\
\text { physical health, } \\
\text { (3) bodily pain, (4) } \\
\text { emotional } \\
\text { problems, (5) } \\
\text { emotional well- } \\
\text { being, (6) social } \\
\text { functioning, (7) }\end{array}$ & ND & IA & $\begin{array}{l}\text { Setswana } \\
\text { and isiZulu }\end{array}$ & Yes \\
\hline
\end{tabular}




\begin{tabular}{|c|c|c|c|c|c|c|c|c|c|}
\hline & & & & & $\begin{array}{l}\text { energy or fatigue, } \\
\text { (8) general health }\end{array}$ & & & & \\
\hline $\begin{array}{l}\text { Debpuur et } \\
\text { al, } 2010 \text { [33] }\end{array}$ & $\begin{array}{l}\text { WHO- } \\
\text { SAGE- } \\
\text { INDEPTH }\end{array}$ & ND & Valid & Yes & $\begin{array}{l}\text { (1) physical, (2) } \\
\text { psychological, (3) } \\
\text { social, (4) } \\
\text { environmental }\end{array}$ & ND & IA & $\begin{array}{l}\text { Kassim } \\
\text { and } \\
\text { Nankam }\end{array}$ & Yes \\
\hline $\begin{array}{l}\text { Hamren et al, } \\
2015 \text { [34] }\end{array}$ & CASP-12 & $\begin{array}{l}\text { Cronbachs } \alpha= \\
0.67, \text { (control) } \\
0.76 \\
\text { (autonomy) } \\
0.63 \\
\text { (pleasure) } \\
0.70 \text { (self- } \\
\text { realisation) }\end{array}$ & Valid & Yes & $\begin{array}{l}\text { (1) control, (2) } \\
\text { autonomy, (3) self- } \\
\text { realization, (4) } \\
\text { pleasure }\end{array}$ & ND & IA & Amharic & Yes \\
\hline $\begin{array}{l}\text { Botes et al, } \\
2018 \text { [47] }\end{array}$ & $\begin{array}{l}\text { EQ-5D+C } \\
\text { and CAF }\end{array}$ & ND & Valid & Unknown & $\begin{array}{l}\text { (1) mobility, (2) } \\
\text { self-care, (3) daily } \\
\text { activities, (4) } \\
\text { pain/discomfort, } \\
\text { (5) } \\
\text { anxiety/depression }\end{array}$ & ND & SA & English & ND \\
\hline $\begin{array}{l}\text { Gerber et al, } \\
2016 \text { [20] }\end{array}$ & EQ-6D & ND & Valid & Yes & $\begin{array}{l}\text { (1) mobility, (2) } \\
\text { self-care, (3) } \\
\text { activity, (4) pain, } \\
\text { (5) anxiety, (6) } \\
\text { cognition, }\end{array}$ & $\begin{array}{l}15 \\
\text { mins }\end{array}$ & IA & English & ND \\
\hline $\begin{array}{l}\text { Akinyemi et } \\
\text { al, } 2010 \text { [29] }\end{array}$ & $\begin{array}{l}\text { Adapted } \\
\text { AMS }\end{array}$ & ND & Valid & Yes & $\begin{array}{l}\text { (1) psychological, } \\
\text { (2) somatic, (3) } \\
\text { sexuality }\end{array}$ & ND & IA & Yoruba & Yes \\
\hline
\end{tabular}

$\mathrm{ND}=$ Not Described; IA = Interviewer Administered; SA = Self-Administered; ICC = Intra Class Correlation

WHOQOL = World Health Organization Quality of Life Scale; SWLS = Satisfaction with Life Scale; WHOQOL-OLD = World Health Organization Quality of Life Scale- OLD version; WHOQOL-BREF = World Health Organization Quality of Life Scale- brief version; SF-36 =Short-Form Health Survey-36 item; SF-12 = Short-Form Health Survey 12-item; WHO-SAGE-INDEPTH = World Health Organization Study on Global Ageing and Adult Health-INDEPTH; CASP = Control, Autonomy, Self-Realization and Pleasure; EQ-5D+C = EuroQol-5D+C; $\mathrm{CAF}=$ Currently Achieved Functioning; EQ-6D = Six-Dimensional EuroQoL; AMS = Aging Male Symptoms .

Figures 


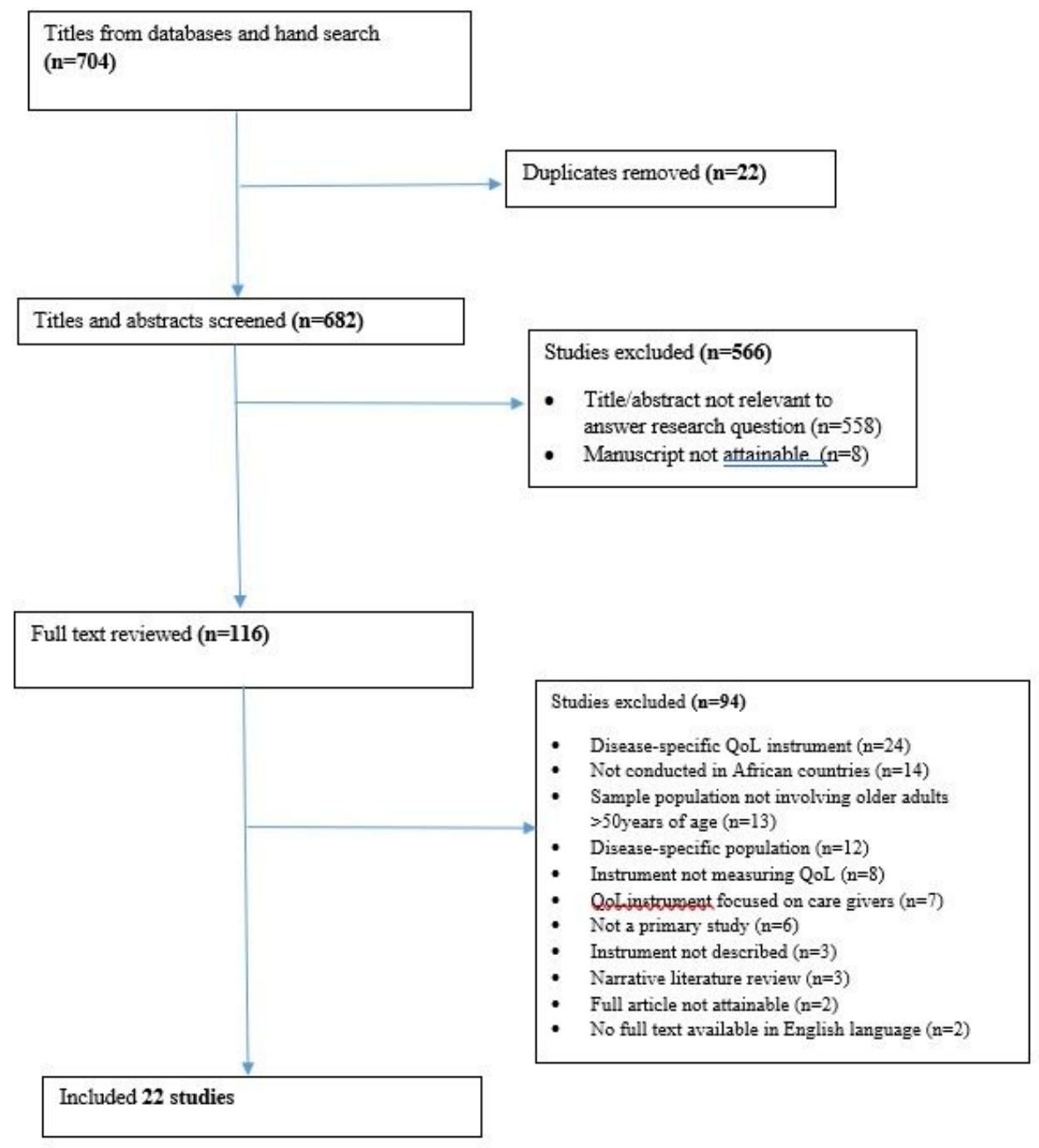

Figure 1

Schematic flow of search results 